\title{
Antagonistic Antibacterial Effect of Betel and Red Betel Combination against Gram-positive and Gram-negative Bacteria
}

\author{
Yustina Sri Hartini*, Yohanes Medika Seta Diaseptana, \\ Rakhel Nugraheni Putri and Lia Elisa Susanti
}

Faculty of Pharmacy, Sanata Dharma University, Sleman, Yogyakarta, Indonesia

*Corresponding author

\section{A B S T R A C T}

\begin{tabular}{|c|}
\hline Keywords \\
\hline $\begin{array}{l}\text { Piper betle, L. Piper } \\
\text { crocatum Ruiz \& Pav, } \\
\text { Combination, } \\
\text { Antagonistic, } \\
\text { Antibacterial }\end{array}$ \\
\hline Article Info \\
\hline $\begin{array}{l}\text { Accepted: } \\
04 \text { April } 2018 \\
\text { Available Online: } \\
10 \text { May } 2018\end{array}$ \\
\hline
\end{tabular}

Treatment with a combination of drugs has been used as an approach to overcome bacterial resistance. The combination of compounds can have synergistic, addictive, or antagonistic effects. The synergistic effect of antibacterial compounds combined is expected to increase antibacterial activity so as to prevent the occurrence of resistance. Betel (Piper betle L.) and red betel (Piper crocatum Ruiz \& Pav.) leaves have antibacterial activity. This study compared the antibacterial activity of betel, red betel, to the combinations of betel and red betel. The antibacterial activity was measured using paper disk diffusion method, against Gram positive and Gram negative bacteria. The combination of betel and red betel showed the lower antibacterial activity than betel or red betel alone. The effect of betel and red betel combination showed antagonistic antibacterial activity against Staphylococcus aureus, Staphylococcus epidermidis or Eschericia coli. The results showed that there was no significant difference between betel and red betel antibacterial activity against the three bacteria. There is a decrease in activity when betel and betel red are combined, compared to their single material. It seemed that there was an antagonistic effect when they are combined so that it is recommended to use them separately.

\section{Introduction}

Betel (Piper betle L.) and red betel (Piper crocatum Ruiz \& Pav.) are species of Piper genus. These plants usually grown in gardens of Indonesian people's houses. In addition to their beautiful appearance, the leaves of both plants are traditionally used for the treatment of various diseases, especially antibacterial. Bacterial infections were initially thought to be overcome by the discovery of penicillin antibiotics isolated from natural ingredients. Antibiotics can even be synthesized so that the treatment of bacterial infections does not have to depend on the source of natural ingredients. However, the current problem of bacterial resistance to antibiotics shows that single compounds have not been able to overcome bacterial infections, therefore new antibacterial or combinations of compounds that can overcome bacterial resistance are required. The combination of compounds can have synergistic, addictive, or antagonistic effects. The combination of natural ingredients shows an increase in antibacterial activity against some pathogens but there is also a 
decrease in antibacterial activity compared with the singular material (Khalil et al., 2013; Semeniuc et al., 2017). Betel and red betel antibacterial activity has been reported (Khan and Kumar, 2011; Divyalashmi and Sharmili, 2017; Junairiah et al., 2015; Karsono et al., 2015). Moreover, betel showed the greatest antibacterial activity among 12 medicinal plants tested against Gram positive and Gram negative bacteria that resistant to various drugs (Demetrio et al., 2015). There have been no previous studies on antibacterial effect of the combination of betel and red betel. In this study, we aimed to compare the antibacterial activity of betel and red betel alone to the combination of betel and red betel against Staphylococcus aureus, Staphylococcus epidermidis, (Gram positive bacteria) and Escherichia coli (Gram negative bacteria)

\section{Materials and Methods}

Sample of betel (Piper betle L.) and red betel (Piper crocatum Ruiz \& Pav.) leaves were collected from Sleman Yogyakarta Indonesia at the end of 2016 (Figure 1). The determination of plants was performed at Faculty of Biology Universitas Gadjah Mada. Herbarium of both plants was deposited in Pharmaceutical Laboratory, Faculty of Pharmacy Sanata Dharma University. After drying, the leaves were powdered by using a blender. The material infundation/extraction was carried out by heating in a water bath for 15 minutes $\left(90^{\circ} \mathrm{C}\right)$ with stirred. The betel and red betel combination is made by mixing each of $20 \mathrm{ml}$ of betel and $20 \mathrm{ml}$ red betel extract respectively (1: 1 ratio $100 \% \mathrm{w} / \mathrm{v})$.

The bacteria used in this study were Staphylococcus aureus, Staphylococcus epidermidis (Gram positive bacteria) and Escherichia coli (Gram negative bacteria). They were obtained from Health Research Laboratory of Yogyakarta Province Indonesia. The bacteria were grown and maintained on
Mueller Hinton Agar. The inoculum size of each bacterium was standardized to Mac Farland II standard.

The antibacterial activity was measured using disk diffusion method. Standardized bacteria were poured into Mueller Hinton Agar medium. The empty disk (6 $\mathrm{mm}$ in diameter) was soaked for 30 minutes in the betel extract, red betel extract, or combination of betel and red betel extract, respectively. Then, it was placed on an inoculated petri dish using sterilized tweezers. An empty disk soaked in sterile water was used for the negative control. Each treatment was repeated 3 times, and then it was incubated for 24 hours at $37^{\circ} \mathrm{C}$.

\section{Results and Discussion}

The antibacterial activity test method used in this study worked well. All bacteria $(S$. aureus, S. epidermidis and E. coli) grew well in nutrient agar media, no visible contamination of other microorganisms. Antibacterial activity of ampicillin-sulbactam as positive controls against these three bacteria can be demonstrated using this test method (Figure 2). Figure 3 showed the inhibitory zone diameter of betel, red betel, and the combination of betel and red betel against $S$. aureus, S. epidermidis, and E. coli. Statistical analysis of inhibitory zone diameter data of antibacterial activity against $S$. aureus, $S$. epidermidis, and $E$. coli showed that there was a significant difference between material test (betel, red betel and combination of betel and red betel, ampicillin-sulbactam) and solvent (negative control). It means that betel, red betel, combination betel and red betel, ampicillin-sulbactam show antibacterial activity against $S$. aureus, S. epidermidis, or $E$. coli. Although the number of betel inhibition zones is larger than red betel, but statistically is not significantly different. Betel has similar antibacterial activity with red betel, against $S$. aureus, S. epidermidis or E. coli. 


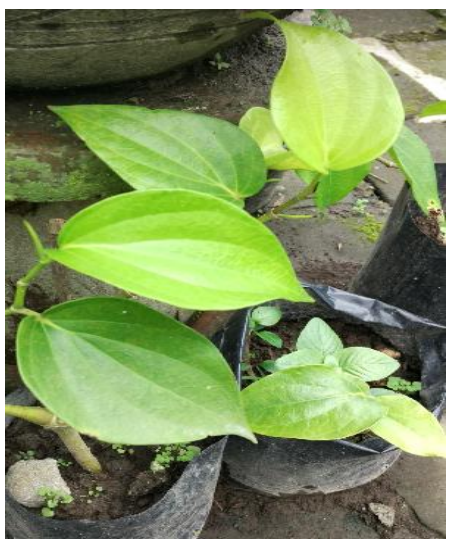

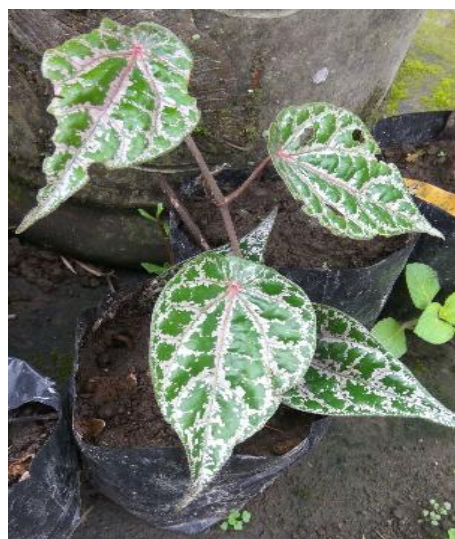

b

Fig.1 Betle (Piper betle, L.) (a) and red betle (Piper crocatum Ruiz \& Pav.) (b)

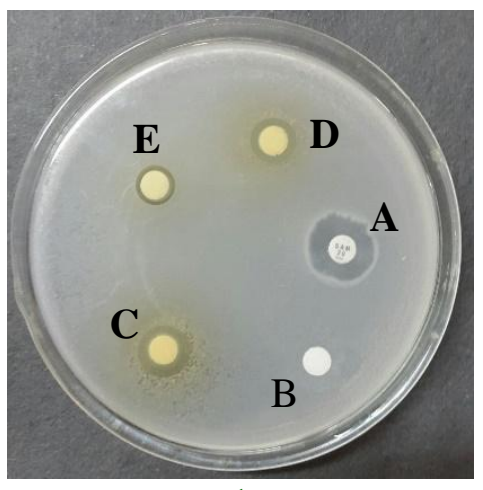

1

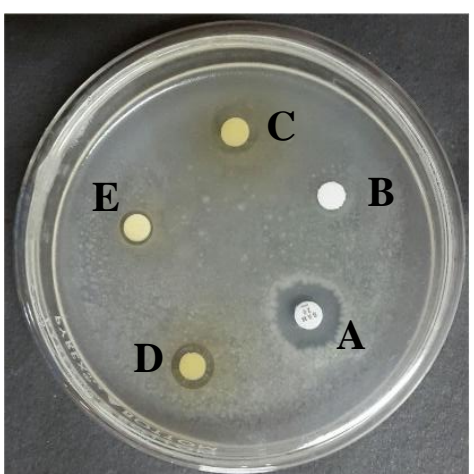

2

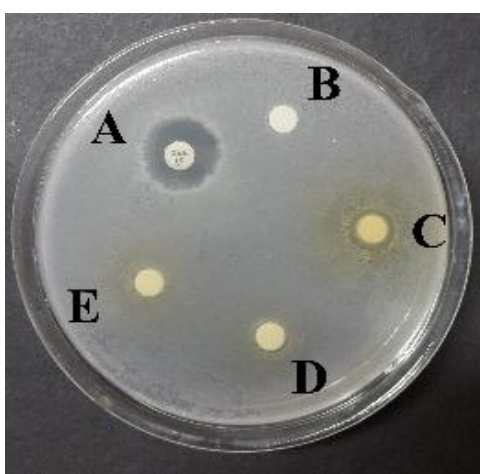

3

Fig.2 The inhibition zone of antibacterial activity of ampicillin-sulbactam (A), solvent (B), betel (C), red betel (D), betel and red betel combination (E) against $S$. aureus (1), S. epidermidis (2), and E. coli (3)

Ampicillin_sulbactam

Combination P. betle \& P. crocatum

P. crocatum

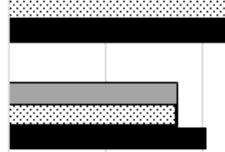

P. betle

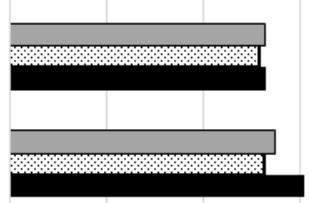

0

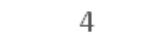

S. epidermidis

S. aureus

Fig.3 The inhibition zone diameter ( $\mathrm{mm}$ ) of betel, red betle, combination of betel and red betel, and ampicillin_sulbactam 
Red betel leaf contains flavonoids, alkaloids, polyphenolates, tannins, and essential oils. The results of analysis of red betel essential oils showed 39 compounds, including cavikol, eugenol, tran-caryopilene, eugenol acetate, and beta-celinen (Safitri and Fahma, 2008; Marliyana et al., 2013). Betel leaf contains alkaloids, phenol, flavonoid, tanin, saponin, glicosyde, terpenoid, steroid, and essential oils. The essential oils contain 5-(2-propenyl)1,3-benzodioxole (25.67\%), eugenol (18.27\%), dan 2-methoxy-4-(2-propenyl) acetate-phenol (8.00\%) (Syahidah et al., 2017; Sugumaran et al., 2011). Essential oils are synthesized by all plant organs, i.e., buds, flowers, leaves, stems, twigs, seeds, fruits, roots, wood or bark, and are stored in secretory cells, cavities, canals, epidermic cells or glandular trichomes (Bakkali et al., 2008). Many researcher reported the antibacterial activity of essential oils. The oxygenated terpenoids, for example alcohols and phenolic terpenes are the most active of them, while some hydrocarbons were usually inactive (Koroch et al., 2007; Ait-Ouazzou et al., 2011). Terpenes, phenylpropenoids, and $\mathrm{N}-\mathrm{S}$ - containing compounds are the three major of secondary metabolites involved in plant chemical defense systems (Wink, 1999). The compounds responsible for betel and red betel antibacterial activity against $S$. aureus, S. epidermidis, or E. coli are probably the essential oils. The essential oils may be the defence compound of betel or red betel against $S$. aureus, S. epidermidis, or E. coli infection. Moreover the results also showed that $S$. aureus bacteria were more susceptible to betel or red betel than those of $S$. epidermidis.

The combination of natural ingredients showed an increase or decrease in antibacterial activity against some pathogens (Khalil et al., 2013; Semeniuc et al., 2017). Betel has similar antibacterial activity with red betel. Both of Piper species have significantly different antibacterial activity to their combination. The combination produces lower activity against $S$. aureus, $S$. epidermidis, and $E$. coli than a single material. It seemed that an antagonistic effect occurred when betel and red betel are combined. The antagonist is a phenomenon when the combination of the compound produces a lower overall effect than the additive effect of the agent alone (Bulusu et al., 2016). The phenomenon of a combination antagonist compound is also reported (Semeniuc et al., 2017). Six different combinations between the Lamiaceae (Ocimum basilicum and Thymus vulgaris) genera and the Apicaeae (Petroselinum crispum and Levisticum officinale) genes against Gram-positive and Gram-negative bacteria produce a lower antibacterial effect than their component alone. Treatment with a combination of drugs has been used as an approach to overcome bacterial resistance, for example in the treatment of malaria and tuberculosis (Nosten amd White, 2007). The discovery of drugs that display better selectivity and possibility of overcoming drug resistance was supported and enhanced by the data of bioactivity and chemical properties combination study (Bulusu et al., 2016). Interactions between compounds may lead to antagonistic, additive, or synergistic effects. The minor components maybe crucial to these effects (Bassole and Juliani, 2012). The interaction between compounds in betel and red betel produces antagonistic effects. Therefore, the use of betel or red betel as an antibacterial is recommended to be used singly, not in combination. The antagonistic effect of a combination of compounds is expected when the presence of a compound leads to undesirable side effects, e.g. due to high doses of the compound. A compound (the main compound) can sometimes not be administered in low doses because the therapeutic effect is attained at that dose. It is necessary to have another compound that 
manages the adverse side effects of the compound, for example by blocking the receptor with such adverse effects. In this case an antagonist role is required by other compounds to cooperate with the main compound and, thus, providing optimal treatment benefits. Synergistic antibacterial effect has been reported from the combination of the essential oils of five plants with antibiotic (Moussaoui and Alaoui, 2016). Moreover, the combination of betel and chloramphenicol showed additive and synergistic effect against $S$. aureus (Taukoorah et al., 2016). The plant and antibiotics combination could be useful in the fight against emerging bacterial drug resistance.

The betel and red betel have an equal antibacterial activity against Staphylococcus aureus, Staphylococcus epidermidis, or Escherichia coli. There was an antagonistic antibacterial effect of the betel and betel red combination. Therefore, the combination is not recommended for Gram positive or Gram negative antibacterial agent.

\section{References}

Ait-Ouazzou A, Cherrat L, Espina L, Lorán S, Rota C, Pagán R. 2011. The antimicrobial activity of hydrophobic essential oil constituents acting alone or in combined processes of food preservation. Innov. Food Sci. Emerg. 12: $320-29$

Bakkali F, Averbeck S, Averbeck D, Idaomar M. 2008. Biological effects of essential oils-A review. Food Chem. Toxicol. 46: 446-475.

Bassole IHN, Juliani HR. 2012. Essential oils in combination and their antimicrobial properties. Molecules.17:3989-4006.

Bulusu KC, Guha R, Mason DJ, Lewis RPI, Muratov E, Motamedi YK, Cokol M, Bender A. 2016. Modelling of compound combination effects and applications to efficacy and toxicity: state-of-the-art, challenges and perspectives. Drug Discovery Today, 21(2): 225-38.

Demetrio L, Valle J., Andrade JI, Puzon JM, Cabrera EC, Rivera WL. 2015. Antibacterial activities of ethanol extracts of Philippines medicinal plants against multidrugs-resistant bacteria. Asian Pacific Journal of Tropical Biomedicine. 5(7):532-540.

Divyalashmi L, Sharmili SA. 2017. Phytochemical Analysis and Antibacterial Activity of Mangifera indica $\mathrm{L}$ and Piper betle. Int $\mathrm{J}$ Pharm Bio Sci. 8(2): 84-91.

Junairiah, Nurhayati T, Ni'matuzahroh, Suwito H. 2015. Effectiveness of Piper crocatum Ruiz and Pav. Calus Elicitation as Antimicrobial Agents. J. Appl. Environ. Biol. Sci. 5(4):197-201.

Karsono, Patilaya P, Azisah, Nerdy. 2015. Comparison of Antimicrobial Activity of Red Betel (Piper crocatum Ruiz \& Pav.) Leaves Nanoparticel and Powder Ethanolic Extract against Methicillin Resistant Staphylococcus aureus. International Journal of Pharm Tech Research. 8(4):696-701.

Khalil, AT, Ahmad K, Khan YA, Khan M., Khan MJ. 2013. Synergistic antibacterial effect of honey and Herba Ocimi basillici against bacterial pathogens. Journal of Traditional Chinese Medicine.33 (6): 810-14.

Khan JA, Kumar N. 2011. Evaluation of Antibacterial Properties of Extracts of Piper betel Leaf. Journal of Pharmaceutical and Biomedical Sciences. 11(01): 1-3.

Koroch A, Juliani HR, Zygadlo JA. 2007. Bioactivity of Essential Oils and Their Components. In Flavours and Fragrances Chemistry, Bioprocessing and Sustainability. Berger, R.G., Ed.; 
Springer Verlag: Berlin, Germany. pp. $87-115$

Marliyana SD, Handayani N, Ngaisah S, Setyowati, EN. 2013. Antibacterial Activity of The Essential Oils Piper crocatum Ruiz \& Pav leaves. Alchem Journal Penelitian. 9(2): 33-40.

Moussaoui F, Alaoui T. 2016. Evaluation of antibacterial activity and synergistic effect betwee antibiotic and the essential oils of some medicinal plants. Asian Pacific Journal of Tropical Biomedicine. 6(1):32-37.

Nosten F, White NJ. 2007. Artemisinin-Based Combination Treatment of Falciparum Malaria, Am J. Trop. Med. Hyg. 77(Suppl 6): 181-92.

Ramon-Garcia S, Carol Ng, Anderson $\mathrm{H}$, Chao JD, Zheng X, Gay Y, Roberge M, Thompsom. 2011. Synergistic Drug Combinations for tuberculosis therapy identified by a novel high-throughput screen. Antimicrobial Agents and Chemotherapy. Agustus: 3861-69.

Safitri M, Fahma F. 2008. Potency of Piper crocatum Decoction as an Antihiperglycemia, Hayati, Journal of Bioscience. 15(1): 45-48.

Semeniuc CA, Pop CR, Rotar AM. 2017. Antibacterial activity and interactions of plant essential oils combinations against Gram-positive and Gram-negative bacteria. Journal of Food and Drug Analysis. 25: 403-08.

Sugumaran M, Poornima M, Venkatraman S, Laksmi M, Srinivasansethuvani. 2011. Chemical composition and antimicrobial activity of sirugamani variety of Piper betle Linn Leaf Oil. Journal of Pharmacy Research. 4(10):3424-26.

Syahidah A, Saad CR, Hassan MD, Rukayadi Y, Norazian MH, Kamarudin MS. 2017. Phytochemical Analysis, Identification and Quantification of Antibacterial Active Compound in Betel Leaves, Piper betle Methanolic Extract. Pakistan Journal of Biological Sciences. 20(2): 70-81.

Taukoorah U, Lall N, Mahomoodally. 2016. Piper betle L. (betel quid) shows bacteriostatic, additive, and synergistic antimicrobial action when combined with conventional antibiotics, South African Journal of Botany. 105:133-40.

Wink M. 1999. Functions of Plant Secondary Metabolites and Their Exploitation in Biotechnology; Sheffield Academic Press: Sheffield UK, Pp. 362.

\section{How to cite this article:}

Yustina Sri Hartini, Yohanes Medika Seta Diaseptana, Rakhel Nugraheni Putri and Lia Elisa Susanti. 2018. Antagonistic Antibacterial Effect of Betel and Red Betel Combination against Gram-positive and Gram-negative Bacteria. Int.J.Curr.Microbiol.App.Sci. 7(05): 267-272. doi: https://doi.org/10.20546/ijcmas.2018.705.035 